er dan minder toe. Waar het vertrouwen in de objectieve 'logica' van de geschiedenis zoek is ("the future was nicier") is het bijna voorspelbaar dat men opnieuw aandacht krijgt voor de particulariteit van de actoren op het historische toneel en, meer in het bijzonder, voor het belang dat de psychologische eigenschappen van politieke actoren $k$ an hebben voor het verloop van het politieke.

Onderhavige reader heeft tot doel om de politieke psychologie als 'jonge' discipline te introduceren, en er de productiviteit op uiteenlopende vraagstellingen van te illustreren.. Dat gebeurt aan de hand van zesentwintig korte essays over uiteenlopende onderwerpen als autoritarisme, etnocentrisme, politieke besluitvormingsprocessen, het onderwijsvak 'maatschappijleer', ideologie en subjectiviteit, politieke antropologie, partijpropaganda, vijandbeelden en dergelijke meer. Het boek bevat een grote waaier aan invalshoeken en benaderingswijzen, gezien er noch van één psychologische wetenschap, noch van één politieke wetenschap kan gesproken worden. Dat kan reeds blijken uit het feit dat niet één van de in de (overigens onvolledige) lijst van werken aan het einde van het boek als een 'standaardwerk' in de politieke psychologie wordt aangewend. Enkel de studie van Adorno e.a. over The Authoritarian Personality (1950) wordt door drie auteurs geciteerd en door nog meerdere gebruikt. De andere studies moeten het doorgaans met één verwijzing stellen. Anderzijds zal men tevergeefs zoeken naar referenties naar bijvoorbeeld het werk van De Tocqueville, Mosca, Gramsci of, zeg maar, Merton - auteurs die men in deze context toch wel zou verwachten.

Daarmee wil geenszins gezegd zijn dat deze inleiding tot de politieke psychologie geen boeiende lectuur zou zijn. Er word t enorm veel informatie op luttele bladzijden aan de lezer gepresenteerd, en men verwerft door de lectuur inzicht in de rijkdom aan invalshoeken die kunnen worden gehanteerd in een analyse van het politieke gebeuren. Maar juist die rijkdom, die telkens opnieuw door een interdisciplinaire aanpak wordt geschraagd doet me twijfelen of politieke psychologie als zodanig werkelijk een nieuw en vruchtbaar paradigma $\mathrm{kan}$ heten. Wat het boek, integendeel, aantoont is dat de vroegere sociologismen leeg waren in de mate waarin zij (en dat was zeer vaak het geval) niet bij machte waren om enerzijds hun theorieën met relevant empirisch materiaal te onderstutten en om anderzijds aan de volle particulariteit van specifieke actoren in het politieke proces plaats te geven. De politieke psychologie vult hier een hiaat. Of dit voldoende is om van een nieuwe discipline te kunnen gewagen, zal de toekomst moeten uitwijzen. Alvast verschijnt ondertussen sedert 1979 het driemaandelijkse tijdschrift Political Psychology om te pogen ons daarvan te overtuigen.

Koen RAES

\title{
OVER DE MENS
}

Cor Schavemaker \& Harry Willemsen, Over de wardigheid van de mens. Alphen aan den Rijn/Brussel, Samsom, 1986(2), 109 blz. ISBN 9014046027.

Een goede wijn behoeft geen krans. De bespreking van dit boek kan dan 
ook kort zijn. Maar ook van goede wijn is het goed om weten waarvoor hij goed is (een goede tafelwijn is daarom nog niet geschikt voor de wildtafel). En dit is een boek bestemd voor de studententafel, zoals de reeks waarin het is verschenen ("Symposion - Teksten voor filosofieonderwijs") duidelijk aangeeft.

Jammer genoeg laat het boek door zijn titel Over de wardigheid van de mens een meer academische en verouderde aanpak suggereren dan het in feite te bieden heeft. Aan het woord komen, over het thema van de menselijke waardigheid, niet alleen de 'belegen' filosofen Kant, Marx en Nietzsche, en hun nog gistende twintigste eeuwse collega's Lévi-Strauss, Gabriel Marcel en Emmanuel Levinas, maar ook de zoveel levensechtere stemmen van Etty Hillesum en Simone Weil, De tekstbezorgers zijn ook niet de filosofen van eigen bodem vergeten (A. Herzberg, A. De Wilde en D.F. Scheltens) en sluiten hun bloemlezing, op een verrassende maar zeer terechte wijze, af met de officiële tekst van de Universele Verklaring van de Rechten van de Mens. Het kranteknipsel op de allerlaatste bladzijde, over "Geweld tegen homo's", komt wat geïsoleerd en té bewust modieus over, maar kan anderzijds op studentenniveau misschien een succesvolle richting aanwijzen voor een verdere concretisering van de problematiek.

De wijze waarop de teksten zijn weergegeven, ingeleid, samengevat en van tussentitels voorzien is op een uitstekende manier 'schools', zonder saai of simplistisch te zijn. In tegenstelling tot de meeste studieboeken, waar de studenten over gapen en de leraars van gruwelen, geeft dit boek je bepaald weer zin de bibliotheek in te duiken en bijvoorbeeld een monografie over het onderwerp te schrijven. Dat de teksten niet altijd van eenzelfde niveau zijn is geen bezwaar. Studenten zijn dat ook niet, en 'niveau' staat in de filosofie helaas maar al te vaak gelijk met on begrijpelijkheid.

En daarmee heeft deze wijn dus toch zijn krans gehad.

Patricia DE MARTELAERE Aangesteld Navorser N.F.W.O.

\section{MENSEN EN MACHINES}

Pieter Vroon en Douwe Draaisma, De mens als metafoor. Baarn, Ambo, \& Schoten, Westland, 1985, 271 blz., 650 Bfr., ISBN 9026306989.

De ondertitel 'Over vergelijkingen van mens en machine in filosofie en psychologie' zegt over dit boek meer dan de eigenlijke titel die toch vrij dubbelzinnig blijft. Het is immers niet duidelijk of de auteurs willen stellen dat de mens 'slechts' een metafoor is. Of bedoelen zij dat over de mens slechts in metaforen kan worden gesproken ? Indien het zo is, is het opnieuw niet duidelijk of de aanduiding 'slechts' een zekere ontgoocheling verhult of inhoudt. Het boek krijgt verder een mooi motto van Cicero mee : "De geest weet zelf niet wat de geest is", en de auteurs rechtvaardigen dit motto als volgt : "Omdat de geest geen toegang tot zichzelf kan krijgen, is er geen andere mogelijkheid dan te zoeken naar een bekend analogon dat iets van de geest aan het licht brengt. Het merendeel van die aanknopingspunten blijkt in het westerse denken uit machines en auto- 